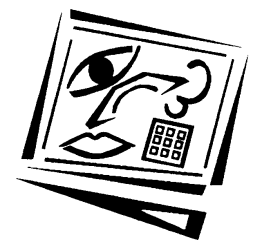

\title{
Blended learning: Investigating its potential in an English language teacher training program
}

\author{
Zeynep Kocoglu, Yesim Ozek and Yesim Kesli \\ Yeditepe University
}

\begin{abstract}
Although the benefits of blended learning have been well documented in educational research, relatively few studies have examined blended learning in language teacher education. This study discusses a blended learning approach for a teacher training program designed for in-service English language teachers, and investigates its effectiveness by comparing with a face to face MA Program in English Language teaching. The research involved 39 in-service English language teachers, with 12 studying in a blended course (i.e., they received face to face instruction in the classroom and used web-based materials) and 27 in a traditional classroom. Results indicated that there was no difference in content knowledge acquisition between teachers receiving blended instruction and teachers receiving face to face instruction.
\end{abstract}

\section{Introduction}

The utilisation of information and communication technologies (ICTs) in educational processes evidently leads to changes in the roles of both teachers and learners, and paves the way to the emergence of new teaching and learning environments and methodologies (e-learning, web-based learning, open and distance learning, and blended learning). Research over the past several years has indicated that students learn as successfully in online environments as in traditional face to face classroom settings (Donnely, 2010; Woltering, Herrler, Spitzer \& Spreckelsen, 2009). However, recently, it has also been accepted that online learning with a single course delivery mode cannot provide optimum conditions for successful learning. Therefore, educators have combined face to face instruction with online learning components and online course management tools in a blended learning format, to join the best features of in-class teaching, to promote active, self-directed learning opportunities with added flexibility (Garnham \& Kaleta, 2002). The purpose of this article is to discuss a blended learning approach for a teacher training program designed for in-service Turkish teachers teaching English as a foreign language (EFL), and assess its effectiveness, using two versions of an MA Program in English Language Teaching (ELT): a blended e-ELT program and a face to face ELT program.

\section{Related literature}

Combining the advantages of e-learning and traditional learning environments has led to a new learning environment often referred to as "blended learning", which brings together traditional physical classes with elements of virtual learning (Finn \& Bucceri, 2004; Garrison \& Kanuka, 2004). One of the basic concepts underlying this approach is that: 
Those who use blended approaches base their pedagogy on the assumption that there are inherent benefits in face-to-face interaction (both among learners and between learner and instructor) as well as the understanding that there are some inherent advantages to using online methods in their teaching. Thus the aim of those using blended learning approaches is to find a harmonious balance between online access to knowledge and face-to-face human interaction (Osguthorpe \& Graham, 2003, p. 228).

In a review of research on blended learning, Bekele and Menchaca (2008) identified many studies that revealed positive influences of blended learning on (1) student performance (Ladyshewsky, 2004; Motteram, 2006); (2) student participation and motivation (DeGeorge-Walker \& Keeffe, 2010; Lopez-Perez, Perez-Lopez \& RodriguezAriza, 2011; Ugur, Akkoyunlu \& Kurbanoglu, 2011), (3) increased access and flexibility (Macedo-Rouet, Ney, Charles \& Lallich-Boidin, 2009), (4) cost-effectiveness (Herman \& Banister, 2007); and (5) more active and deeper learning (Bonk, Kim \& Zeng, 2006; Cooner, 2010) in comparison with traditional classes (Donnely, 2010; Woltering, Herrler, Spitzer \& Spreckelsen, 2009).

In an attempt to take advantage of blended learning, universities have begun offering courses combining traditional face to face instructional elements with online learning components (Mitchell \& Forer, 2010) in various academic fields, such as management (Arbough, 2005) and business (Holsapple \& Lee-Post, 2006). However, little research has been done on blended learning in teacher education specifically (Young \& Lewis, 2008), and published work has focused generally on students' opinions and on the technological applications introduced (Lopez-Perez, Perez-Lopez \& Rodriguez-Ariza, 2011). However, blended learning may have great potential to improve teacher education with respect to both accessibility and quality.

\section{Blended learning in teacher education}

Research studies have been conducted to examine different aspects of blended learning in teacher education. King (2002), Motteram (2006), and Young and Lewis (2008) examined the perception of teacher candidates in blended teacher education programs and concluded that they had positive ideas about blended education in terms of overall satisfaction and enjoyment. In another study, Owston, Sinclair and Wideman (2008) reported that a blended program for middle school mathematics and science teachers positively influenced teacher attitudes and content knowledge on specific curricular topics, and motivated many teachers to transform their classroom practice.

Harrell and Harris (2006), for instance, compared performance of teacher candidates in the blended program to those in the traditional face to face program. Findings of the study indicated that the blended program significantly increased the number of candidates entering teaching in the areas of science and mathematics. Holmes, Polhemus and Jennings (2005) and Voogt, Almekinders, van den Akke and Monen (2005) analysed blended courses for an in-service professional development program for K-12 teachers that focused on integrating technology into teachers' practices. These studies suggested that blended programs can help teachers better understand and implement technology into their classrooms and, to a lesser extent, adapt exemplary materials for their own settings.

The above literature review signifies the importance of studying the application of blended learning in teacher education not only at the course level, but also at the program level. There is a particular lack of research on blended learning in language 
teacher education at the program level. Blended learning has integrated into various teacher education programs such as biology education (Saunders \& Klemming, 2003), human services education (Adcock, et.al. 2006), or science education (Liang \& She, 2006). However, there have been only a few studies reporting the use of these programs for foreign/second language teaching (Crisp, 2006; Thirunarayanan \& PerezPrado, 2001). To the researchers' knowledge, only three studies conducted by Kupetz and Ziegenmeyer (2005), Harker and Koutsantoni (2005) and Ozek, Kesli and Kocoglu (2009) have investigated blended learning approaches in the context of English language teacher education.

Kupetz and Ziegenmeyer (2005) described the development process for a blended learning approach using various multimedia-based case stories and electronic tools such as 'e-interview'. Each of these activities was designed to support different aspects of student learning and to be flexible enough to respond to the needs of different types of learners. They concluded that the blended learning approach can "support the integration of declarative and procedural knowledge, thus supporting the learner when constructing professional knowledge and skills."

Harker and Koutsantoni (2005) focused on blended learning effectiveness of an English for academic purposes (EAP) program designed for students from diverse ethnic backgrounds. Comparisons on student retention, achievement levels and satisfaction with the program between the two groups of students suggest that performance and satisfaction levels were similar in the two groups, the blended learning mode being significantly superior only in terms of student retention.

Ozek, Kesli and Kocoglu (2009), on the other hand, investigated attitudes of teachers towards blended courses, and found that in-service EFL teachers had positive attitudes towards blended programs. The present study will be a follow up study to the Ozek, Kesli and Kocoglu (2009) study which investigated the effectiveness of a blended language teacher education program compared to a face to face, traditional program.

\section{Aim of study}

The aim of this study was to determine the effects of a blended learning program on in-service English language teachers' content knowledge of their teaching profession.

\section{Methodology}

\section{Design}

This was a quasi-experimental study with a non-equivalent groups design. Traditional face to face classroom teaching and blended course utilising e-learning components was administered to control and experimental groups.

\section{Context of the study}

In Turkey, the Higher Education Act of 1981 required Anadolu University to design an Open Education System as a national distance education program. The University started to offer a BA program in language teacher education in 2000 (Latchem, Özkul, Aydin \& Mutlu, 2006), which is the only ELT program offered via distance education in Turkey. The first two years of this program are carried out by traditional (face to 
face) education, while the last two years are conducted wholly by distance education with online support for each class.

The first attempt to initiate an Internet based English language teaching MA program (e-ELT) within a blended learning framework was realised by Yeditepe University's English Language Teaching Department. Within the framework of this program, the University aimed to develop and implement an interactive, student centered, and Internet based program to support the professional development of English language teachers in Turkey (Eveyik-Aydin, in progress). The courses offered in this blended program have been selected from among the courses that were already offered within the current English Language Teaching MA program (i.e., Introduction to Second Language Acquisition, Principles of Foreign Language Testing, and Methodology in English Language Teaching). The researchers uploaded course syllabi, reading texts, videos, lecture notes and activities for the face to face group to a Moodle environment. The research team chose Moodle (http: / / moodle.org/) as it was free, open source software. The researchers designed activities by using activity modules such as quizzes, tests and discussion forums.

To facilitate student-student and student-teacher interactions, a discussion forum was also included, allowing students to post questions, make comments, and respond to comments made by other students. The researchers also designed PowerPoint presentations for each course. The blended group used the same PowerPoint course slides as the face to face group. The main difference came from the live interaction in the face to face classes. The face to face format allowed for immediate answers to questions and discussions, whereas the online format did not allow for this, but the blended group had the opportunity of reviewing the presentations as many times as needed. The face to face group interacted orally, and the blended group used a discussion board. The participants were registered to the class and they received online training for how the online course would be conducted, what was expected of them, how they would complete weekly assignments, how they would upload their assignments, and how they would reach the instructor or their classmates whenever they had questions. After an initial orientation, the classes started. All instructional groups attended the same courses and the program, and followed the same syllabi for both forms of instruction. The blended group, in addition, for one week in each semester, stayed on the university campus for face to face instruction. Also, the course instructors visited the schools for face to face instruction for 2 days each semester.

\section{Participants}

Thirty-nine EFL teachers (27 female and 12 male; age range 24-35 years) participated to the research. All the participants were English language teachers with a bachelor's degree. A total of 25 teachers taught in secondary school; 14 of them in the university's preparatory school.

For this project, 12 English language teachers from four Anatolian high schools volunteered to participate in the project as the experimental group. They were taught in a blended learning environment (i.e., they received face to face instruction in the classroom and used web-based materials). The control group of the project, on the other hand, included 27 teachers who were enrolled in an on campus MA program in English Language Education offered by the same department. They were taught by lecture only (i.e., they received face to face instruction) in classrooms. The study period was from September 2008 to December 2008. 


\section{Data collection}

This quasi-experimental study explored the differences between two groups exposed to different treatments (i.e., blended instruction versus traditional face to face instruction) as reflected in the dependent variable (i.e., content knowledge). Content knowledge was defined by (a) the Teaching Knowledge Test (TKT), (b) final course grades and (c) focus group interviews.

a. The Teaching Knowledge Test (TKT): TKT is a test from Cambridge ESOL about teaching English to speakers of other languages. This test basically measures the content knowledge of:

- different methodologies for teaching,

- the ways in which resources can be used in language teaching,

- the key aspects of lesson planning, and

- classroom management methods for different needs.

This test was used as a pre-test to see whether the teachers in control and experimental groups differed from each other in terms of background knowledge. The online group received the pre-test via email which was designed by using Survey Monkey software.

b. Final course grades: Final course grades were collected for each course given by instructors to see how much they acquired content knowledge. The course assignments, exams, projects and quizzes were the same for both experimental and control groups to minimise confounding factors. In this program, content knowledge was defined as the grades teachers received for the courses (i.e., AA 90100, BA 85-89, BB 80-84, CB 75-79, and CC 70-74) and it was interpreted as their estimation of amount learned in the course.

c. Open-ended questions such as discussing their experiences about the blended instruction, the problems they faced, and their suggestions for the improvement of the program were asked in the feedback questionnaire. These questions were asked and answered in English.

\section{Data analysis}

The researchers wanted to learn which type of instruction would yield higher content learning in a MA program offered via face to face instruction or blended instruction. The aim of this study was to determine the effects of a blended learning program on in-service English language teachers' content knowledge. The dependent variable was content knowledge while the independent variable was type of instruction: face to face versus blended instruction. The main hypothesis predicted a significant difference in the content knowledge of the participants, regardless of whether they participated in the blended or face to face course delivery methods. Demographic characteristics were analysed by descriptive statistics, and the homogeneity of the experimental and control group was analysed by the independent sample $t$ test. The null hypothesis was tested at the .05 level of significance (i.e., alpha value).

The qualitative data were collected through the feedback questionnaire in which the blended group was asked four questions about the blended instruction they received. 


\section{Findings}

In order to find out whether two groups of teachers differ in terms of content knowledge before starting to the program, TKT test was given as a pre-test. Descriptive statistics and the independent sample $t$-test were conducted. The mean scores for TKT test were of two groups after the program. As indicated in Table 1, the mean scores for content knowledge after the program were $62.00(\mathrm{SD}=7.568)$ in the blended group and $64.44(\mathrm{SD}=6.961)$ in the face to face group $(t=0.798, p=0.383)$, indicating that there was no significant difference between the content knowledge of the blended group and the face to face group at the beginning of the program.

Table 1: Independent samples $t$-test for the TKT test scores

\begin{tabular}{|l|c|c|c|c|c|}
\hline & F & Sig & $t$ & $d f$ & Sig 2-tail \\
\hline Equal variances assumed & .798 & .383 & .799 & 29 & .434 \\
\hline Equal variances not assumed & & & .828 & 18.922 & .418 \\
\hline
\end{tabular}

Note: $\operatorname{Sig}=p$ value; $t=t$ test statistical value; $d f=$ degrees of freedom

In order to determine the effects of a blended learning program on in-service English language teachers' content knowledge for their teaching, descriptive statistics and the independent samples $t$-test were conducted on course grades of two groups after the program. As shown in Table 2, the mean scores for content knowledge after the program were $3.50(\mathrm{SD}=0.674)$ in the blended group and $3.56(\mathrm{SD}=0.726)$ in the face to face group $(t=0.014, p=0.949)$.

Table 2: Independent samples $t$-test results for course grades

\begin{tabular}{|l|c|c|c|c|c|}
\hline & F & Sig & $t$ & $d f$ & Sig 2-tail \\
\hline Equal variances assumed & .014 & .949 & .181 & 29 & .858 \\
\hline Equal variances not assumed
\end{tabular}

It was found that there was no significant difference between the content knowledge of the blended group and the face to face group at the beginning of the program. This indicated that the treatment did not increase course grade scores, which means that the learners learned almost the same amount of material through blended instruction and face to face instruction.

\section{Opinions on the blended instruction}

At the end of semester, an open ended questionnaire was given to the blended group to obtain responses concerning various aspects of blended instruction. Summaries and relevant quotations from the four questions are presented below:

1. What do you think of the blended approach implemented in your MA program? Most participant responses were positive indicating that it was beneficial, motivating and helpful to be able to share and discuss opinions:

I had problems in talking in front of the class, but with the use of discussion forums in Moodle system, I felt relieved.

Blended course was fun and easier to learn especially the theoretical part of the field. 
I like the way of teaching the class - online. Definitely, I will use it with my younger students.

Personally I like taking classes in the classroom; however, I think that the courses I took online were also nice.

2. What would you do to improve this blended program? What are your suggestions? Participants were satisfied with the program and did not think it needed to be improved overall. They appreciated the program because it made it possible for them to be able to attend an MA program and to accomplish their career goals.

I was satisfied with the program.

I do not have any suggestions for improvement other than those minor weaknesses.

Participants also offered constructive criticism on various aspects of the blended course. For example, participants made the following comments:

The PowerPoint slides took so much time to download. The computer center must find a solution to this problem.

It took a long time to download testing videos and watch. I need to update my computer.

3. For which courses do you think using online components is beneficial?

Content was also considered as an important factor when determining the effectiveness of blended instruction. Participants commented that courses such as theories were appropriate for the online environment, whereas courses such as testing and teaching methods were more appropriate for face to face classroom instruction due to the need for direct guidance and personal interaction:

I enjoy online format. The assessment course was taught online and this was an appropriate class to attend on the site.

The skills course was the only class that would not be easy to do at home without guidance.

Participants also commented on the blended program's convenience and flexibility, such as the flexibility of classes to fit their work schedules and how they were able to complete the program at their own pace:

I did not have to complete the readings in a set time, I could complete it at my own time.

4. What are the advantages and disadvantages of the blended learning environment? Some participants mentioned fewer disadvantages such as unresponsive instructors and the overwhelming workload.

I had some instructors who did not respond immediately.

Some teachers did not give feedback to papers until the end.

Some participants specified the lack of peer interaction and lack of personal, face to face conversation as a disadvantage related to blended program:

I sometimes need to talk and see my peers. 
I wanted to talk in person with my professors while doing an assignment.

In sum, those teachers who received blended instruction mentioned the convenience and flexibility of the program, and managing their own pace to finish the program. They also felt that the program supported their professional development as a teacher.

\section{Discussion and conclusions}

This study has confirmed the research that advocates blended courses as useful and as effective as face to face courses, but contradicted the research that supported the superiority of blended courses over traditional face to face courses in terms of student learning. This study found that (1) course objectives were achieved in the blended environment as in face to face and (2) the same degree of learning outcomes was achieved in the blended learning environment as in the traditional. This study indicated that a blended course provides a comprehensive and comparable learning environment to the traditional program. Despite concerns raised in a variety of previous research studies (e.g., Chen \& Jones, 2007; Modritscher, 2006), the content knowledge scores of participants in blended instruction in this study were not significantly higher or lower than those in traditional instruction.

Blended and face to face courses used the same textbooks with the same instructors, measured the same student learning outcomes and covered the same topics. The findings showed that students performed well and are as successful as the traditional, face to face students. Therefore, blended course delivery method is an acceptable alternate method to circulate information at a distance to provide with additional educational opportunities. Learning in an online environment has been found to be as effective and valuable as in the traditional sense.

Harrell and Harris (2006) and Young and Lewis (2008) discovered that teacher candidates have generally positive response to blended learning in terms of overall satisfaction and enjoyment. The results of this study also supported those findings on student satisfaction.

The results of this study provide evidence for teacher education professionals to understand how blended instruction may contribute to teacher education. The findings support the viability and benefits of applying blended learning in teacher education at the program level. By combining online classes and face to face learning, a teacher education program is able to increase its convenience, flexibility, access, and efficiency while maintaining the quality of the program. As Young and Lewis (2008) commented, "education professionals in teacher education programs should begin the uncomfortable conversations regarding the viability of training teachers at a distance" (p. 608). Therefore, the results of this study may encourage educators to implement ICT technologies into their teacher training programs.

The present study also had various limitations. First, the number of participants in the blended course was relatively small. In addition, the number of the participants for each group was not equal. Therefore, solid assurances cannot be made of the generalisability of the results to other contexts. Results from this study have provided insight to some queries, but at the same time have uncovered other areas of concern that require additional research such as attrition, sample size, student perception of method of instruction, learning styles, and instructor teaching style and approach. Technology is ever changing; therefore, it is essential that schools conduct ongoing 
research into their programs in order to ascertain how they can best facilitate continued development and refinement of blended courses or programs which will achieve desired outcomes.

There is a need for ongoing research to examine effectiveness of web-based course delivery. Also, studies should include components such as faculty preference for teaching blended versus traditional instruction.

This research's findings support the idea that there is equivalence in student achievement between blended and traditional face to face instruction. However, for future research, the study should be replicated with a larger population other than English language teachers.

\section{Acknowledgment}

We would like to thank Professor Dr Ayse Semra Akyel, our dean, for her enthusiasm, support and encouragement throughout this project.

\section{References}

Adcock, A. B., Dugan, M., Nelson, E. \& Nickel, C. (2006). Teaching effective helping skills at a distance: The development of project CATHIE. Quarterly Review of Distance Education, 7(4), 349-360.

Arbough, J. B. (2000). Virtual classroom characteristics and student satisfaction with Internetbased MBA courses. Journal of Management Education, 24(1), 32-54. http: / / dx.doi.org/10.1177/105256290002400104

Bekele, T. A. \& Menchaca, M. (2008). Research on Internet-supported learning: A review. Quarterly Review of Distance Education, 9(4), 373-406.

Bonk, C. J., Kim, K.-J. \& Zeng, T. (2006). Future directions of blended learning in higher education and workplace learning settings. In C. J. Bonk \& C. R. Graham (Eds.), The handbook of blended learning: Global perspectives, local designs (pp. 550-567). San Francisco, CA: Pfeiffer.

Chen, C. C. \& Jones, K. T. (2007). Blended learning vs. traditional classroom settings: Assessing effectiveness and student perceptions in an MBA accounting course [Electronic version]. The Journal of Educators Online, 4(1), 1-15. http: / / www.thejeo.com/Volume4Number1/JonesFinal.pdf

Cooner, T. S. (2010). Creating opportunities for students in large cohorts to reflect in and on practice: Lessons learnt from a formative evaluation of students' experiences of a technologyenhanced blended learning design. British Journal of Educational Technology, 41(2), 271-286. http: / / dx.doi.org/10.1111/j.1467-8535.2009.00933.x

Crisp, P. (2006). E-learning and language and style in Hong Kong. Language E Literature, 15(3), 277-290. http: / / dx.doi.org/10.1177/0963947006066127

De George-Walker, L. \& Keeffe, M. (2010). Self-determined blended learning: A case study of blended learning design. Higher Education Research \& Development, 29(1), 1-13. [verified 27 Oct 2011] http:/ / eprints.usq.edu.au /8603/2/De_George-Walker_Keeffe_HERD_v29n1_AV.pdf

Donnelly, R. (2010). Harmonizing technology with interaction in blended problem-based learning. Computers $\mathcal{E}$ Education, 54(2), 350-359. http: / / dx.doi.org/10.1016/j.compedu.2009.08.012 
Eveyik-Aydin, E. (in progress). A clarificative evaluation of an Internet-based MA program in English Language Teaching (e-ELT) project at Yeditepe University. Unpublished manuscript.

Finn, A. \& Bucceri, M. (2004). A case study approach to blended learning. [not found 27 Oct 2011] http:/ / www.centra.com/download/whitepapers / CaseStudy-BlendedLearning.pdf

Garnham, C. \& Kaleta, R. (2002, March). Introduction to hybrid courses. Teaching with Technology Today, 8(6). http: / / www.uwsa.edu/ttt/articles/garnham.htm

Garrison, D. R. \& Kanuka, H. (2004). Blended learning: Uncovering its transformative potential in higher education. The Internet and Higher Education, 7(2), 95-105. http: / / dx.doi.org/10.1016/j.iheduc.2004.02.001

Harker, M. \& Koutsantoni, D. (2005). Can it be as effective? Distance versus blended learning in a web-based EAP programme. ReCALL, 17(2), 197-216. http: / / dx.doi.org/10.1017/S095834400500042X

Harrell, P. E. \& Harris, M. (2006). Teacher preparation without boundaries: A two-year study of an online teacher certification program. Journal of Technology and Teacher Education, 14(4), 755774. http:/ / www.editlib.org/p/18913

Herman, T. \& Banister, S. (2007). Face-to-face versus online coursework: A comparison of costs and learning outcomes. Contemporary Issues in Technology and Teacher Education, 7(4), 318-326. http: / / www.editlib.org/d/24250

Holmes, A., Polhemus, L. \& Jennings, S. (2005). CATIE: A blended approach to situated professional development. Journal of Educational Computing Research, 32(4), 381-394. http: / / dx.doi.org/ 10.2190/ F97W-QUJ4-G7YG-FPXC

Holsapple, C. W. \& Lee-Post, A. (2006). Defining, assessing and promoting e-learning success: An information systems perspective. Decision Sciences Journal of Innovative Education, 4(1), 6785. http: / / dx.doi.org/ 10.1111/j.1540-4609.2006.00102.x

King, K. P. (2002). Identifying success in online teacher education and professional development. The Internet and Higher Education, 5, 231-246. http:/ / dx.doi.org/10.1016/S10967516(02)00104-5

Kupetz, R. \& Ziegenmeyer, B. (2005). Blended learning in a teacher training course: Integrated interactive e-learning and contact learning. ReCALL, 17(2), 179-196. http: / / dx.doi.org/10.1017/S0958344005000327

Ladyshewsky, R. K. (2004). E-learning compared with the face to face: Differences in the academic achievement of postgraduate business students. Australasian Journal of Educational Technology, 20(3), 316-336. http:/ / www.ascilite.org.au/ ajet/ ajet20/ladyshewsky.html

Latchem, C., Özkul, A. E., Aydin, C. H. \& Mutlu, M. E. (2006). The Open Education System, Anadolu University, Turkey: E-transformation in a mega-university. Open Learning, 21(3), 221-235. http: / / dx.doi.org/10.1080/02680510600953203

Liang, C.-P. \& She, H.-C. (2006). The effects of constructivist-oriented web-based science learning on middle school students "force" concept learning. Chinese Journal of Science Education, 14(5), 493-516. http: / / www.fed.cuhk.edu.hk/en/ cjse/200600140005/0493.htm

Lopez-Perez, M. V., Perez-Lopez, M. C. \& Rodriguez-Ariza, L. (2011). Bended learning in higher education: Students' perceptions and their relation to outcomes. Computers $\mathcal{E}$ Education, 56(3), 818-826. http: / / dx.doi.org/10.1016/j.compedu.2010.10.023

Macedo-Rouet, M., Ney, M., Charles, S. \& Lallich-Boidin, G. (2009). Students' performance and satisfaction with Web vs. paper-based practice quizzes and lecture notes. Computers $\mathcal{E}$ Education, 53, 375-384. http:/ / dx.doi.org/10.1016/j.compedu.2009.02.013

Mitchell, P., \& Forer, P. (2010). Blended learning: The perceptions of first-year geography students. Journal of Geography in Higher Education, 34(1), 77-89. http: / / dx.doi.org/10.1080/03098260902982484 
Modritscher, F. (2006). E-learning theories in practice: A comparison of three methods. Journal of Universal Science and Technology of Learning, 0(0), 3-18. http: / / www.jucs.org/justl_0_0/ elearning_theories_in_practice/justl_0_0_0003_0018_moedritscher.html

Motteram, G. (2006). Blended education and the transformation of teachers: A long-term case study in postgraduate UK higher education. British Journal of Educational Technology, 37(1), 1730. http: / / dx.doi.org/10.1111/j.1467-8535.2005.00511.x

Osguthorpe, R. T. \& Graham, C. R. (2003). Blended learning environments: Definitions and directions. The Quarterly Review of Distance Education, 4(3), 227-233.

Owston, R. D., Sinclair, M. \& Wideman, H. (2008). Blended learning for professional development: An evaluation of a program for middle school mathematics and science teachers. Teachers College Record, 110(5), 1033-1064. http: / / www.tcrecord.org/ Content.asp?ContentID $=14668$

Ozek, Y., Kesli, Y. \& Kocoglu, Z. (2009). Integrating a web-based learning program into a traditional learning environment: Students' attitudes and expectations. US-China Education Review, 6(11), 80-86.

Saunders, G. \& Klemming F. (2003). Integrating technology into a traditional learning environment: Reasons for and risks of success. Active Learning in Higher Education, 4(1), 74-86. http: / / dx.doi.org/10.1177/1469787403004001006

Thirunarayanan, M. O. \& Perez-Prado, A. (2001). Comparing web-based and classroom-based learning: A quantitative study. Journal of Research on Technology in Education, 34(2), 131-137. http: / / www.iste.org/Store/ Product.aspx?ID=1874

Ugur, B., Akkoyunlu, B. \& Kurbanoglu, S. (2011). Students' opinions on blended learning and its implementation in terms of their learning styles. Education and Information Technologies, 16(1), 5-23. http: / / dx.doi.org/10.1007/ s10639-009-9109-9

Voogt, J., Almekinders, M., van den Akke, J. \& Monen, B. (2005). A blended in-service arrangement for classroom technology integration: Impacts on teachers and students. Computers in Human Behavior, 21(3), 523-539. http: / / dx.doi.org/10.1016/ j.chb.2004.10.003

Woltering, V., Herrler, A., Spitzer, K. \& Spreckelsen, C. (2009). Blended learning positively affects students' satisfaction and the role of the tutor in the problem-based learning process: Results of a mixed-method evaluation. Advances in Health Science Education, 14(5), 725-738. http: / / dx.doi.org/10.1007/ s10459-009-9154-6

Young, A. \& Lewis, C. W. (2008). Teacher education programmes delivered at a distance: An examination of distance student perceptions. Teaching E Teacher Education, 24(3), 601-609. http: / / dx.doi.org/10.1016/j.tate.2007.03.003

Authors: Assistant Professor Zeynep Kocoglu

Department of Foreign Language Education, Faculty of Education, Yeditepe University, 26 Agustos Campus, Kayisdagi Cad., 34755 Kayisdagi, Istanbul, Turkey Email: zbkocoglu@yeditepe.edu.tr

Dr Yesim Ozek, Faculty of Education, Yeditepe University.

Email:yozek@yeditepe.edu.tr

Dr Yesim Kesli, Faculty of Education, Yeditepe University.

Email: ykesli@yeditepe.edu.tr

Please cite as: Kocoglu, Z., Ozek, Y. \& Kesli, Y. (2011). Blended learning: Investigating its potential in an English language teacher training program. Australasian Journal of Educational Technology, 27(7), 1124-1134.

http: / / www.ascilite.org.au/ajet/ajet27/ kocoglu.html 